\title{
PENGARUH PEMANFAATAN TEKNOLOGI INFORMASI DAN KOMPETENSI SUMBER DAYA MANUSIA TERHADAP EFEKTIVITAS SISTEM INFORMASI AKUNTANSI
}

\author{
Natalia Paranoan ${ }^{1}$, Christina Jeane Tandirerung ${ }^{1}$, Anthon Paranoan ${ }^{1}$ \\ Jurusan Akuntansi, Fakultas Ekonomi, Universitas Kristen Indonesia Paulus \\ Makassar \\ nataliaparanoan@gmail.com \\ christinajt@gmail.com \\ anthonparanoan@gmail.com
}

\begin{abstract}
This study is aimed to test and analyze the effect of information technology usage and human resource competencies on the effectiveness of accounting information system. This study used primary data with survey method by distibuted questionnaires to employees of PT. X Makassar. The samples were defined by using purposive sampling method. This study distributed 50 questionnaires but only 45 questionnaires were returned and could be processed. Data that already collected were analyzed by multiple linear regression. The results show that information technology usage had positive and not significant effect to the effectiveness of accounting information system, and human resource competencies had positive and significant effect to the effectiveness of accounting information system. While information technology usage and human resource competencies simultaneous affect to the effectiveness of accounting information system.
\end{abstract}

Keywords: Information Technology Usage; Human Resource Competencies; Effectiveness of Accounting Information System.

\begin{abstract}
ABSTRAK
Penelitian ini bertujuan untuk menguji dan menganalisis pengaruh pemanfaatan teknologi informasi akuntansi dan kompetensi sumber daya manusia terhadap efektivitas sistem informasi akuntansi. Penelitian ini menggunakan data primer melalui metode survei dengan menyebar 50 kuesioner kepada pegawai PT. X di Makassar. Penentuan sampel dilakukan dengan metode purposive sampling dan responden yang mengembalikan kuesioner dan dapat diolah sebanyak 45 kuesioner. Selanjutnya, data yang telah dikumpulkan dianalisis dengan regresi linier berganda. Hasil pengujian menunjukkan bahwa pemanfaatan teknologi informasi berpengaruh positif dan tidak signifikan terhadap efektivitas sistem informasi akuntansi, sedangkan kompetensi sumber daya manusia berpengaruh positif dan signifikan terhadap efektifitas sistem informasi akuntansi. Sementara, pemanfaatan teknologi informasi dan kompetensi sumber daya manusia secara simultan berpengaruh terhadap efektivitas sistem informasi akuntansi.
\end{abstract}

Kata Kunci: Pemanfaatan Teknologi Informasi; Kompetensi Sumber Daya Manusia; Efektivitas Sistem Informasi Akuntansi

Jurnal Akun Nabelo: Jurnal Akuntansi Netral, Akuntabel, Objektif Volume 2/Nomor 1/Juli 2019 Jurusan Akuntansi FEB-Universitas Tadulako

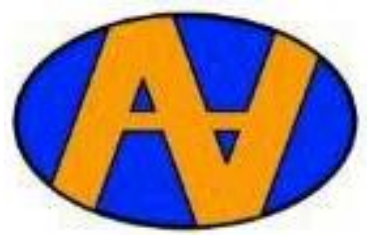


“Jurnal Akun Nabelo” Volume 2/Nomor 1/Juli 2019 (Hal. 181 - 196)

\section{A. PENDAHULUAN}

Teknologi adalah salah satu bentuk perubahan yang dapat membantu perusahaan untuk mencapai tujuannya. Munculnya teknologi informasi telah mempengaruhi bentuk dan substansi informasi, begitu juga dengan akuntansi. Sistem informasi akan memberikan kemudahan bagi para manajemen untuk menghasilkan informasi keuangan yang dipercaya, relevan, tepat waktu, dapat dipahami dan teruji sehingga membantu pengambilan keputusan.

Ismanto (2010) menyatakan bahwa teknologi informasi memiliki peran yang strategis dan signifikan. Selain itu, teknologi informasi bagi organisasi atau perusahaan merupakan keharusan untuk mampu dikuasai secara teknis. Teknis kinerja dari sebuah sistem informasi adalah menangkap, mentransmisikan, menyimpan, mengambil, memanipulasi, dan menampilkan informasi guna meningkatkan kualitas yang diperlukan dalam proses pengambilan keputusan. Oleh karena itu, pemakaian sebuah sistem informasi sangat berperan dalam organisasi atau perusahaan.

Pengembangan sistem informasi akuntansi (SIA) dapat menambah nilai bagi perusahaan, yaitu menghasilkan informasi yang akurat dan tepat waktu.

Penggunaan SIA dapat meningkatkan kualitas informasi, mengurangi biaya informasi, meningkatkan ketepatan dalam pengambilan keputusan, dan meningkatkan pembagian pengetahuan (knowledge sharing). Output dari sistem informasi akuntansi adalah informasi-informasi yang akan berguna dalam mengukur kinerja keuangan dan menghasilkan laporan keuangan perusahaan yang akurat. Dalam penyusunan laporan keuangan tidak jarang terdapat kesalahan-kesalahan ataupun ketidakakuratan dalam pencatatan. Pemanfaatan teknologi informasi dalam hal ini penggunaan komputer dapat membantu proses pengumpulan informasi lebih cepat dan akurat.

Salah satu faktor yang mempengaruhi kinerja sistem informasi akuntansi adalah perilaku manusia. Sumber daya manusia adalah pelaksana dan penunjang sistem informasi akuntansi yang berjalan pada institusi atau perusahaan tersebut. Perilaku manusia dalam organisasi perlu dipertimbangkan dalam menyusun sistem informasi akuntansi karena sistem informasi itu tidak mungkin berjalan tanpa manusia.

Penelitian ini didukung atas teori kontijensi yang dapat menjadi dasar dalam terciptanya efektivitas sistem informasi akuntansi. Menurut teori kontijensi, efektivitas sistem informasi akuntansi dipengaruhi oleh efek teknologi, lingkungan, dan struktur organisasi. Efek teknologi berhubungan dengan penggunaan sistem informasi pada perusahaan tersebut, sementara efek lingkungan serta struktur organisasi tidak lepas kaitannya dari karyawan yang bekerja pada perusahaan tersebut.

PT. X adalah produsen semen terbesar di kawasan timur Indonesia yang berusaha meningkatkan nilai perusahaan kepada para pemegang saham dan pemangku kepentingan dengan strategi yang berfokus pada kegiatan bisnis utama. Dalam rangka mencapai sasaran tersebut, teknologi informasi dan sumber daya manusia yang baik memiliki peran yang sangat penting untuk membantu dalam proses bisnis dan pengambilan keputusan dalam perusahaan. Di lain pihak, sumber daya manusia pada PT. X seringkali dianggap kurang maksimal dalam bekerja. Oleh karena itu, peneliti bermaksud melakukan penelitian pada perusahaan tersebut untuk melihat keefektivitasan sistem informasi akuntansi perusahaan. 
Penelitian ini bertujuan untuk menyelidiki pengaruh pemanfaatan teknologi informasi terhadap efektivitas sistem informasi akuntansi pada PT. X Makassar. Selain itu, penelitian ini juga mempertimbangkan pengaruh kompetensi sumber daya manusia terhadap efektivitas sistem informasi akuntansi. Secara teoritis, hasil dari penelitian ini dapat dijadikan sebagai salah satu sumbangan data empiris yang bermanfaat sebagai masukan dan menambah wawasan mengenai sistem informasi akuntansi dan kaitannya dalam menunjang efektivitas kinerja perusahaan. Secara praktis, hasil penelitian ini dapat bermanfaat sebagai masukan dan bahan pertimbangan dalam penerapan sistem informasi akuntansi pada perusahaan dalam mencapai perbaikan kinerja di masa yang akan datang. Selain itu, penelitian ini pun dapat menjadi bahan referensi untuk penelitian selanjutnya sebagai kontribusi untuk pengembangan ilmu sistem informasi akuntansi ke depan.

\section{B. TELAAH PUSTAKA}

\section{B.1. Teori Kontijensi}

Teori kontijensi merupakan konsep yang dirumuskan oleh Drazin dan Van de Ven. Teori ini mengajukan tiga pendekatan penting dalam riset kontijensi, yaitu seleksi (selection), interaksi (interaction), dan sistem (system). Teori kontijensi dalam arti luas menyatakan bahwa keefektivitasan organisasi merupakan suatu fungsi kesesuaian antara sistem lingkungan di mana suatu organisasi tersebut beroperasi. Teori kontijensi merupakan alat pertama dan yang paling terkenal untuk menjelaskan berbagai variasi dalam struktur organisasi.

Faktor kontijen secara tidak langsung menciptakan kebutuhan-kebutuhan dalam integrasi informasi yang dibutuhkan untuk koordinasi dan pengendalian organisasi. Teori kontijensi mendukung terwujudnya efektivitas sistem informasi akuntansi. Penerapan teori dalam sistem informasi akuntansi erat kaitannya dengan efek teknologi, efek lingkungan, dan efek struktur organisasi. Struktur organisasi, lingkungan, dan teknologi informasi merupakan tiga faktor penting yang saling berhubungan dalam peningkatan kinerja dan efektivitas organisasi.

Pemakaian SIA dalam suatu perusahaan dilihat dari seorang pengguna komputer meningkatkan kemampuannya dalam menggunakan computer. Dengan demikian semakin mahir pemakai maka semakin efektif penerapan sistem informasi akuntansi di suatu perusahaan yang akan mengakibatkan meningkatnya kinerja individual yang bersangkutan (Sari, 2009).

B.2. Faktor-faktor yang Mempengaruhi Kinerja Sistem Informasi Akuntansi

Faktor-faktor yang mempengaruhi kinerja sistem informasi akuntansi antara lain perilaku manusia dalam organisasi karena sistem informasi akuntansi tidak dapat berjalan tanpa manusia dan penggunaan metode kuantitatif yang mana menjadi dasar dalam pengambilan keputusan. Akibatnya, keputusan manajemen akan lebih terarah sehingga keputusan yang akan dibuat lebih efektif.

\section{B.3. Teknologi Informasi}

Teknologi informasi merupakan aspek penting dalam organisasi (perusahaan). Teknologi informasi akan bernilai pada saat digunakan dalam organisasi (perusahaan) untuk mencapai tujuan strategis dan operasional organisasi (perusahaan). Oleh karena itu, banyak perusahaan mengeluarkan 
“Jurnal Akun Nabelo” Volume 2/Nomor 1/Juli 2019 (Hal. 181 - 196)

dana untuk membuat teknologi informasi yang memadai. Infrastruktur tersebut terdiri dari komputer, teknologi informasi, program teknikal, dan database.

Menurut Warsita (2008:135), teknologi informasi adalah sarana dan prasarana (hardware, software, useware) sistem dan metode untuk memperoleh, mengirimkan, mengolah, menafsirkan, menyimpan, mengorganisasikan, dan menggunakan data secara bermakna. Hal yang sama juga diungkapkan oleh Lantip dan Riyanto (2011:4) bahwa teknologi informasi diartikan sebagai ilmu pengetahuan dalam bidang informasi yang berbasis komputer dan perkembangannya sangat pesat. Uno dan Lamatenggo (2011:57) juga mengemukakan bahwa teknologi informasi adalah suatu teknologi yang digunakan untuk mengolah data. Pengolahan itu termasuk memproses, mendapatkan, menyusun, menyimpan, memanipulasi data dalam berbagai cara untuk menghasilkan informasi yang berkualitas, yaitu relevan, akurat, dan tepat waktu.

Pengetahuan mengenai teknologi informasi bukan sekadar pengetahuan secara teknis, akan tetapi lebih pada kekuatannya secara strategis. Teknologi informasi yang diterapkan tersebut harus acceptable, artinya dapat diterima oleh semua orang yang akan menggunakannya. Jika perkembangan teknologi tidak acceptable, maka dapat menimbulkan perilaku yang tidak diharapkan seperti resistance to change (penolakan terhadap perubahan).

Resistance to change muncul karena tidak semua orang mudah menerima perubahan dan menganggap bahwa adanya perubahan berarti hambatan, bahkan dapat merupakan ancaman. Resistance to change juga dapat timbul karena kurangnya pengetahuan atau ketidakmampuan dalam mengoperasikan teknologi informasi yang baru. Sebaliknya, bagi orang-orang yang dinamis, perkembangan teknologi informasi merupakan dorongan untuk semakin mengembangkan diri.

Teknologi yang semakin berkembang menyebabkan pengolahan data menggunakan alat elektronik seperti komputer sangat menguntungkan. Sistem informasi akuntansi didefinisikan sebagai sistem berbasis komputer yang memproses informasi keuangan dan mendukung keputusan tugas dalam konteks koordinasi dan mengendalikan kegiatan organsasi.

Sistem akuntansi berbasis komputer memiliki beberapa kelebihan, yaitu dapat meningkatkan efisiensi khususnya jika volume data yang diolah cukup besar, pengolahan data dengan menggunakan komputer lebih mudah karena komputer bisa melakukan perhitungan secara otomatis, dan komputer mampu menyajikan informasi secara cepat dan dengan kecermatan yang tinggi. Selain kelebihan tersebut, komputer memiliki beberapa kelemahan antara lain komputer hanya alat, komputer memerlukan program aplikasi, dan komputer terbatas pada kemampuan alogoritmis.

\section{B.4. Sumber Daya Manusia (SDM)}

Sumber daya manusia adalah aset perusahaan yang paling berharga, begitulah pernyataan dari para manajer perusahaan. Sebagaimana kita ketahui bahwa dalam perusahaan itu, akun kas, aset berwujud dan tidak berwujud non manusia lainnya itu sebenarnya dikendalikan oleh manusia. Manusia yang mengelola suatu perusahaan, manusia pula yang menciptakan nilai tambah, dan tanpa sumber daya manusia perusahaan tidak akan bisa menghasilkan laba sebagai nilai tambah bagi perusahaan itu sendiri.

Kompetensi sumber daya manusia dalam melaksanakan suatu fungsi, termasuk akuntansi, dapat dilihat dari level of responsibility dan kompetensi 
sumber daya tersebut. Kompetensi merupakan suatu karakteristik dari seseorang yang memiliki keterampilan (skill), pengetahuan (knowledge), dan kemampuan (ability) untuk melaksanakan suatu pekerjaan (Nurillah, 2014). Menurut beberapa pakar, kompetensi adalah karakteristik yang mendasari seseorang mencapai kinerja yang tinggi dalam pekerjaannya. Pegawai yang tidak mempunyai pengetahuan yang cukup akan bekerja tersendat-sendat dan juga mengakibatkan pemborosan bahan, waktu, dan tenaga (Nurillah, 2014).

Sistem informasi akuntansi (SIA) merupakan kumpulan sumber daya manusia (SDM) beserta modal yang memiliki tugas dalam menyiapkan informasi keuangan dan informasi non keuangan. Berdasarkan pernyataan tersebut, dapat disimpulkan bahwa sumber daya manusia berperan penting dalam terwujudnya keefektivitasan sistem informasi akuntansi.

\section{B.5. Penelitian Terdahulu}

Alaryan et al. (2014) melakukan penelitian mengenai efektivitas sistem informasi akuntansi. Penelitian ini mengemukakan beberapa faktor yang berperan meningkatkan efektivitas sistem informasi akuntansi di Institusi Pendidikan Privat Yordania. Hasil dari penelitian ini membuktikan bahwa sumber daya manusia, hardware, software, dan efisensi database memiliki hubungan yang positif terhadap efektivitas sistem informasi akuntansi.

Nicolaou (2000) melakukan penelitian untuk menganalisis model kontijensi yang merupakan kebutuhan organisasi dan pengendalian. Hasil penelitian ini membuktikan bahwa antara desain sistem informasi akuntansi dan faktor kontijensi menghasilkan efektivitas sistem informasi akuntansi.

Sajady et al. (2008) melakukan penelitian untuk menguji bahwa pengimplementasian sistem informasi akuntansi di perusahaan ini menyebabkan peningkatan manajer dalam pengambilan keputusan, pengendalian internal, dan kualitas laporan keuangan serta memfasilitasi proses transaksi yang terjadi di perusahaan. Hasil dari penelitian ini mengindikasikan bahwa implementasi dari sistem informasi yang baik meningkatkan pengambilan keputusan dan pengendalian internal.

Grande (2011) melakukan penelitian untuk mengukur dan mengidentifikasi hubungan antara sistem informasi akuntansi yang menggunakan small and medium sized enterprises (SMEs) terhadap peningkatan produktivitas kinerja. Hasil dari penelitian ini memperlihatkan bahwa terdapat hubungan positif penggunaan sistem informasi akuntansi terhadap manajemen fiskal dan pengukuran kinerja.

Nurillah (2014) melakukan penelitian untuk menganalisis pengaruh kompetensi sumber daya manusia, penerapan sistem akuntansi keuangan daerah, pemanfaatan teknologi informasi, dan sistem pengendalian intern terhadap kualitas laporan keuangan daerah. Hasil dari penelitian ini adalah kompetensi sumber daya alam, penerapan sistem akuntansi keuangan daerah, pemanfaatan teknologi informasi dan sistem pengendalian intern pemerintah mempunyai pengaruh positif dan signifikan terhadap kualitas laporan keuangan pemerintah daerah.

Yosefrinaldy (2013) melakukan penelitian untuk mengetahui pengaruh kapasitas sumber daya manusia terhadap kualitas laporan keuangan pemerintah daerah, pengaruh pemanfaatan teknologi informasi terhadap kualitas laporan keuangan pemerintah daerah, dan pengaruh sistem pengendalian internal pemerintah terhadap kualitas laporan keuangan 
“Jurnal Akun Nabelo” Volume 2/Nomor 1/Juli 2019 (Hal. 181 - 196)

pemerintah daerah. Hasil penelitian menunjukkan bahwa kapasitas sumber daya manusia berpengaruh signifikan positif terhadap kualitas laporan keuangan pemerintah daerah. Pemanfaatan teknologi informasi berpengaruh signifikan positif terhadap kualitas laporan keuangan pemerintah daerah. Sistem pengendalian internal pemerintah berpengaruh signifikan positif terhadap kualitas laporan keuangan pemerintah daerah.

Winidyaningrum dan Rahmawati (2010) melakukan penelitian untuk mengetahui pengaruh sumber daya manusia dan pemanfaatan teknologi informasi terhadap keterandalan dan ketepatwaktuan pelaporan keuangan pemerintah daerah. Hasil dari penelitian ini adalah sumber daya manusia dan pemanfaatan teknologi informasi memiliki pengaruh positif terhadap keterandalan pelaporan keuangan pemerintah daerah. Pemanfaatan teknologi informasi memiliki pengaruh positif terhadap ketepatwaktuan pelaporan keuangan pemerintah daerah. Sementara itu, kapasitas sumber daya manusia berpengaruh negative terhadap pelaporan keuangan pemerintah daerah.

Damayanthi dan Sierrawati (2013) melakukan penelitian untuk mengetahui pengaruh efektivitas sistem informasi akuntansi dan penggunaan teknologi informasi terhadap kinerja individual pada koperasi simpan pinjam di kecamatan. Hasil dari penelitian ini adalah efektivitas sistem informasi akuntansi dan penggunaan teknologi informasi berpengaruh positif dan signifikan.

Penelitian kali ini berbeda dengan beberapa penelitian di atas. Variabelvariabel yang digunakan pada penelitian ini antara lain adalah pemanfaatan teknologi informasi, sumber daya manusia, dan efektivitas sistem informasi akuntansi. Adapun kerangka pemikirian penelitian ini sebagai berikut.

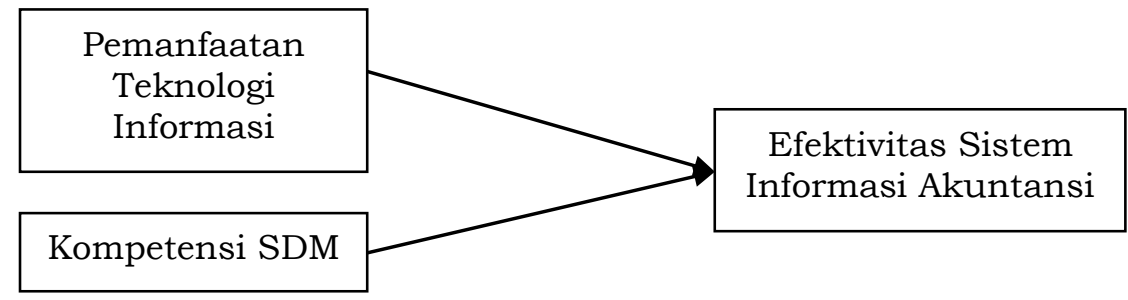

Gambar 1

Kerangka Pemikirian Penelitian

\section{B.6. Hipotesis Penelitian}

B.6.1. Pengaruh Pemanfaatan Teknologi Informasi terhadap Efektivitas Sistem Informasi Akuntansi

Penerapan teori kontijensi (Islam dan Hui Hu, 2012) dalam sistem informasi akuntansi erat kaitannya dengan efek teknologi, efek lingkungan, dan efek struktur organisasi. Struktur organisasi, lingkungan, dan teknologi informasi merupakan tiga faktor penting yang saling berhubungan dalam peningkatan kinerja dan efektivitas organisasi. Teori kontijensi menjelaskan penggunaan informasi akuntansi yang pada akhirnya membantu mengevaluasi kinerja manajemen dan pengambilan keputusan.

Sistem informasi akuntansi dapat dikatakan efektif apabila sistem mampu menghasilkan informasi yang dapat diterima dan memenuhi 
Pengaruh Pemanfaatan Teknologi Informasi dan ... Paranoan, Tandirerung, \& Paranoan

harapan secara tepat waktu (timely), akurat (accurate), dan dapat dipercaya (reliable), dimana dalam mewujudkannya dibutuhkan pemanfaatan teknologi informasi yang memadai dan maksimal. Pemanfaatan teknologi informasi dan proses kerja manajemen dapat dilakukan secara elektronik (Nurillah, 2014).

Ada banyak penelitian mengenai faktor-faktor dalam efektivitas sistem informasi akuntansi. Penelitian Shaheen (2012) yang dikutip oleh Alaryan et al. (2014) bahwa terdapat hubungan positif antara lingkungan, teknologi, dan budaya yang mendukung terciptanya efektivitas dan efisien sistem informasi akuntansi.

Penelitian lain yang menjadi acuan dari penelitian ini adalah penelitian Alaryan et al. (2014) yang menyimpulkan bahwa terdapat hubungan positif antara software dan hardware terhadap efektivitas sistem informasi akuntansi. Penelitian tersebut menjelaskan bahwa penggunaan teknologi dapat membantu organisasi dalam mengolah data dan informasi lebih akurat dan tepat waktu.

Keterangan diatas membuktikan bahwa uraian dan temuan empiris mengenai teknologi informasi menunjukkan bahwa pengolahan data dengan memanfaatkan teknologi informasi (komputer dan jaringan) akan memberikan banyak keunggulan baik dari sisi keakuratan/ketepatan hasil operasi maupun sebagai mesin multiguna maupun mengurangi kesalahan yang mungkin terjadi saat mencatat transaksi keuangan. Berdasarkan penjelasan tersebut, maka hipotesisnya sebagai berikut.

H1: Pemanfaatan teknologi informasi berpengaruh positif dan signifikan terhadap efektivitas sistem informasi akuntansi.

B.6.2. Pengaruh Kompetensi Sumber Daya Manusia terhadap Efektivitas Sistem Informasi Akuntansi

Islam dan Hui $\mathrm{Hu}$ (2012) menjelaskan bahwa dalam teori kontijensi, efek struktur organisasi merupakan salah satu faktor penunjang terciptanya efektivitas perusahaan. Struktur organisasi ialah suatu susunan dan hubungan antara tiap bagian secara posisi yang ada pada perusahaan dalam menjalin kegiatan operasional untuk mencapai tujuan tertentu.

Struktur organisasi ini terdiri dari para pekerja/karyawan dalam hal ini adalah sumber daya manusia pada organisasi tersebut. Beberapa faktor yang menunjang efisiensi dan efektivitas dari sistem informasi akuntansi adalah sumber daya manusia yang berkualitas, software, dan hardware yang memadai, dan database yang terstruktur dengan baik. Alaryan et al. (2014) melakukan penelitian yang membuktikan bahwa terdapat hubungan pofitif antara sumber daya manusia dan efektivitas sistem informasi akuntansi. Berdasarkan penjelasan tersebut, maka hipotesisnya sebagai berikut.

H2: Kompetensi sumber daya manusia berpengaruh positif dan signifikan terhadap efektivitas sistem informasi akuntansi.

B.6.3. Pemanfaatan Teknologi Informasi Dan Kompetensi Sumber Daya Manusia Berpengaruh Terhadap Efektivitas Sistem Informasi Akuntansi

Teknologi informasi merupakan teknologi yang mempunyai kemampuan untuk menangkap, menyimpan, mengolah, mengambil kembali, dan menyebarkan informasi, serta sebagai sarana dalam 
“Jurnal Akun Nabelo” Volume 2/Nomor 1/Juli 2019 (Hal. 181 - 196)

meningkatkan kinerja baik pemerintah maupun perusahaan yang terkait dengan penggunaan teknologi informasi tersebut (Wansyah et al., 2009).

Sumber daya manusia adalah orang yang siap, mau, dan mampu memberikan sumbangan dalam usaha pencapaian tujuan organisasi. Sumber daya manusia harus baik karena sumber daya manusia yang baik akan menunjukkan kapasitas sumber daya yang baik juga. Untuk mencapai tujuan perusahaan, teknologi informasi memiliki peran yang sangat penting terutama dalam menghasilkan informasi bagi perusahaan dan didalamnya didukung oleh kompetensi sumber daya manusia yang baik terutama dalam penggunaan teknologi informasi yang berupa komputer sehingga untuk menghasilkan sistem informasi akuntansi yang baik, seseorang harus memiliki kompetensi yang baik terutama dalam pemanfaatan teknologi informasi. Berdasarkan penjelasan tersebut, maka hipotesisnya sebagai berikut:

H3: Pemanfaatan teknologi informasi dan kompetensi sumber daya manusia berpengaruh simultan terhadap efektivitas sistem informasi akuntansi

\section{METODE PENELITIAN}

\section{C.1. Variabel Penelitian}

\section{C.1.1. Pemanfaatan Teknologi Informasi (X1)}

Pemanfaatan teknologi informasi merupakan penggunaan secara optimal dari komputer (mainframe, mini, micro), perangkat lunak (software), database, jaringan (internet, intranet), electronic commerce, dan jenis lainnya yang berhubungan dengan teknologi (Nurillah 2014). Pemanfaatan teknologi informasi mencakup adanya (a) pengolahan data, pengolahan informasi, sistem manajemen dan proses kerja secara elektronik, dan (b) pemanfaatan kemajuan teknologi informasi agar pelayanan publik dapat diakses dengan mudah dan murah oleh masyarakat.

Jumlah item pernyataan adalah 8 item dengan menggunakan pengukuran skala likert $1-5$, yaitu skor 1 untuk pernyataan sangat tidak setuju, skor 2 untuk pernyataan tidak setuju, skor 3 untuk pernyataan kurang setuju, skor 4 untuk pernyataan setuju, dan skor 5 untuk pernyataan sangat setuju.

\section{C.1.2. Kompetensi Sumber Daya Manusia (X2)}

Kompetensi Sumber Daya Manusia (SDM) merupakan kemampuan, potensi, keahlian, atau kemahiran dari seseorang, pengguna, atau pemakai dalam menggunakan teknologi informasi guna mengolah serta mengelolah data atau informasi akuntansi dari aktivitas operasional organisasi. Jumlah item pernyataan adalah 7 item dengan menggunakan skala likert 1-5, yaitu skor 1 untuk pernyataan sangat tidak setuju, skor 2 untuk pernyataan tidak setuju, skor 3 untuk pernyataan kurang setuju, skor 4 untuk pernyataan setuju, dan skor 5 untuk pernyataan sangat setuju.

\section{C.1.3. Efektivitas Sistem Informasi Akuntansi (Y1)}

Efektivitas sistem informasi akuntansi diharapkan dapat terwujud berdasarkan unsur-unsur SIA dan ditunjang dengan pemanfaatan teknologi informasi dan sumber daya manusia yang baik dan maksimal. Efektivitas sistem informasi akuntansi pada perusahaan sangat penting, 
karena dari hal itulah perusahaan tersebut dapat mengukur keberhasilan sistem informasi yang diterapkan. Jumlah item pernyataan adalah 14 item dengan menggunakan skala likert 1-5, yaitu skor 1 untuk pernyataan sangat tidak setuju, skor 2 untuk pernyataan tidak setuju, skor 3 untuk pernyataan kurang setuju, skor 4 untuk pernyataan setuju, dan skor 5 untuk pernyataan sangat setuju.

\section{C.2. Populasi dan Sampel}

Populasi dalam penelitian ini adalah pegawai PT. X Makassar. Penelitian ini menggunakan purposive sampling yang artinya sampel dipilih berdasarkan kriteria tertentu. Adapun kriteria yang dipilih yaitu pegawai yang bekerja menggunakan komputer dan informasi akuntansi. Jumlah kuesioner yang disebar berjumlah 50 buah dan yang dapat diolah sebanyak 45 buah.

\section{C.3. Teknik Pengumpulan Data}

Penelitian ini menggunakan metode survei dengan kuesioner sebagai teknik pengumpulan data yang diadopsi dari penelitian Alaryan et al. (2014), Nurillah (2014) dan Nicolau (2000) dengan beberapa perbaikan sesuai kebutuhan penelitian.

\section{C.4. Instrumen Penelitian}

Pengukuran variabel menggunakan skala likert. Untuk memperoleh data yang akurat dalam penelitian, instrumen penelitian harus teruji tingkat validitas dan reliabilitasnya. Uji validitas dan reliabilitas dilakukan dengan menggunakan SPSS 20.0. Variabel-variabel dalam penelitian ini diukur dengan menggunakan kuesioner. Kuesioner tersebut akan mengukur jawaban responden melalui pemberian skor yang telah ditentukan dalam bentuk skala likert poin 5 , mulai dari sangat setuju yang akan diberi poin 5 , setuju yang akan diberi poin 4 , kurang setuju yang akan diberi poin 3 , tidak setuju yang akan diberi poin 2 , dan sangat tidak setuju yang akan diberi poin 1, yang akan menghasilkan hasil akhir yang akurat dan tepat.

\section{C.5. Metode Analisis Data}

Metode analisis data yang digunakan dalam penelitian ini adalah analisis regresi linear berganda (multiple linear regression analysis). Analisis regresi linear berganda digunakan untuk memprediksi pengaruh lebih dari satu variabel bebas terhadap satu variabel terikat, baik secara parsial maupun simultan. Penelitian ini menggunakan dua variabel bebas sehingga persamaannya adalah sebagai berikut:

$\mathrm{Y}=\mathrm{a}+\mathrm{b} 1 \mathrm{TI}+\mathrm{b} 2 \mathrm{SDM}+\mathrm{e}$

Keterangan:

$$
\begin{array}{ll}
\mathrm{Y} & =\text { Efektivitas Sistem Informasi Akuntansi } \\
\mathrm{a} & =\text { Konstanta } \\
b 1, b 2 & =\text { Koefisien regresi } \\
T I & =\text { Pemanfaatan Teknologi Informasi } \\
S D M & =\text { Kompetensi Sumber Daya Manusia } \\
\mathrm{e} & =\text { Error }
\end{array}
$$

\section{HASIL DAN PEMBAHASAN}

\section{D.1. Statistik Deskriptif}

Statistik deskriptif dalam penelitian ini berfungsi untuk menggambarkan karakter sampel serta memberikan deskripsi variabel yang digunakan dalam penelitian tersebut. Data dapat dilihat pada Tabel 1. Tabel 1 menunjukkan 
“Jurnal Akun Nabelo” Volume 2/Nomor 1/Juli 2019 (Hal. 181 - 196)

bahwa pemanfaatan teknologi informasi memiliki kisaran empiris antara 30 sampai dengan 40 dengan nilai rata-rata (mean) sebesar 36,02 dan standar deviasi (standar deviation) sebesar 3,093. Dengan nilai rata-rata (mean) sebesar 36,02 yang lebih tinggi dari median sebesar 36 menunjukkan pemanfaatan teknologi informasi telah dimanfaatkan dengan baik.

Tabel 1

Statistik Deskriptif

\begin{tabular}{|l|c|c|c|c|c|c|}
\hline & $\mathrm{N}$ & Min & Max & Mean & Median & $\begin{array}{c}\text { Std. } \\
\text { Deviation }\end{array}$ \\
\hline $\begin{array}{l}\text { Pemanfaatan Teknologi } \\
\text { Informasi }\end{array}$ & 45 & 30 & 40 & 36,02 & 36 & 3,093 \\
\hline $\begin{array}{l}\text { Kompetensi Sumber Daya } \\
\text { Manusia }\end{array}$ & 45 & 25 & 35 & 31,02 & 31 & 2,624 \\
\hline $\begin{array}{l}\text { Efektivitas Sistem Informasi } \\
\text { Akuntansi }\end{array}$ & 45 & 51 & 70 & 60,31 & 60 & 4,522 \\
\hline
\end{tabular}

Sumber: Data primer yang diolah SPSS (2018)

Kompetensi sumber daya manusia memiliki kisaran antara 25 sampai dengan 35 dengan nilai rata-rata (mean) sebesar 31,02 dan standar deviasi (standar deviation) sebesar 2,624. Dengan nilai rata-rata (mean) sebesar 31,02 yang lebih tinggi dari median sebesar 31 menunjukkan bahwa kompetensi sumber daya manusia sangat baik.

Efektivitas sistem informasi akuntansi memiliki kisaran empiris antara 51 sampai dengan 70 dengan nilai rata-rata (mean) sebesar 60,31 dan standar deviasi (standar deviation) sebesar 4,522. Dengan nilai rata-rata (mean) sebesar 60,31 yang lebih tinggi dari median sebesar 60 menunjukkan bahwa efektivitas sistem informasi akuntansi telah berjalan dengan baik.

\section{D.2. Hasil Analisis Regresi Linear Berganda}

Berdasarkan hasil uji regresi pada Tabel 2, persamaan regresi linear berganda, yang dibaca adalah nilai dalam kolom $\mathrm{B}$, baris pertama menunjukkan konstanta (a) dan baris selanjutnya menunjukkan koefisien variabel independen. Model regresi yang digunakan adalah sebagai berikut. $\mathrm{Y}=23,562+0,384 T I+0,738 S D M+e$.

Tabel 2

Hasil Uji t

\begin{tabular}{|c|c|c|c|c|c|}
\hline \multirow{2}{*}{ Model } & \multicolumn{2}{|c|}{ Unstandardized Coefficients } & $\begin{array}{l}\text { Standardized } \\
\text { Coefficients }\end{array}$ & \multirow[t]{2}{*}{$\mathrm{t}$} & \multirow[t]{2}{*}{ Sig. } \\
\hline & $\mathrm{B}$ & Std. Error & Beta & & \\
\hline \multirow{3}{*}{$\begin{array}{l}\text { (Constant) } \\
\text { PTI } \\
\text { KSDM }\end{array}$} & 23,562 & 7,296 & & 3,229 & 0,002 \\
\hline & 0,384 & 0,216 & 0,263 & 1,782 & 0,082 \\
\hline & 0,738 & 0,254 & 0,428 & 2,903 & 0,006 \\
\hline
\end{tabular}

a. Dependent Variable: Y

Sumber: Data primer yang diolah SPSS (2018)

\section{D.3. Hasil Pengujian Hipotesis}

\section{D.3.1. Uji $t$}

Berdasarkan hasil uji statistik $\mathrm{t}$ (Tabel 2), pengaruh dari masingmasing variabel pemanfaatan teknologi informasi (X1), kompetensi sumber daya manusia (X2), terhadap efektivitas sistem informasi akuntansi (Y) dapat dilihat dari tingkat signifikan (probabilitas), arah tanda variabel pemanfaatan teknologi informasi (X1), kompetensi sumber daya manusia (X2), terhadap efektivitas sistem informasi akuntansi (Y) mempunyai arah 
Pengaruh Pemanfaatan Teknologi Informasi dan ... Paranoan, Tandirerung, \& Paranoan

yang positif. Tabel 2 menunjukkan bahwa pemanfaatan teknologi informasi berpengaruh signifikan terhadap efektivitas sistem informasi akuntansi pada probabilitas 0,10. Sementara, kompetensi sumber daya manusia berpengaruh signifikan terhadap efektivitas sistem informasi akuntansi pada probabilitas 0,05.

D.3.1. Uji F

Hasil pengujian $\mathrm{F}$ pada penelitian ini dapat dilihat pada tabel di bawah ini.

Tabel 3

Hasil Uji F

\begin{tabular}{|c|c|c|c|c|c|c|}
\hline & Model & $\begin{array}{c}\text { Sum of } \\
\text { Squares }\end{array}$ & $\mathrm{df}$ & $\begin{array}{c}\text { Mean } \\
\text { Square }\end{array}$ & $\mathrm{F}$ & Sig. \\
\hline \multirow{3}{*}{1} & Regression & 342,535 & 2 & \multirow{3}{*}{$\begin{array}{r}171,267 \\
13,265\end{array}$} & \multirow[t]{3}{*}{12,912} & \multirow[t]{3}{*}{$0,000^{b}$} \\
\hline & Residual & 557,110 & 42 & & & \\
\hline & Total & 899,644 & 44 & & & \\
\hline
\end{tabular}

a. Dependent Variable: ESIA

b. Predictors: (Constant), KSDM, PTI

Sumber: data di olah 2018

Berdasarkan hasil tabel di atas diperoleh nilai $\mathrm{F}$ sebesar 12,912 lebih besar dari $\mathrm{F}$ tabel yaitu 4,07 dengan nilai signifikansi 0,000 lebih kecil dari 0,05, maka model regresi dapat digunakan untuk memprediksi tingkat efektivitas sistem informasi akuntansi pada PT X Makassar atau dapat dikatakan bahwa pemanfaatan teknologi informasi dan kompetensi sumber daya manusia berpengaruh simultan terhadap efektivitas sistem informasi akuntansi.

\section{D.4. Pembahasan}

D.4.1. Pengaruh Pemanfaatan Teknologi Informasi terhadap Efektivitas Sistem Informasi Akuntansi

Hasil uji statistik (Tabel 2) menunjukkan bahwa secara parsial diperoleh nilai t hitung 1,782 lebih besar daripada t tabel 1,681 dengan signifikansi 0,082 yaitu lebih besar dari 0,05. Rasio pemanfaatan teknologi informasi tidak berpengaruh secara parsial terhadap efektivitas sistem informasi akuntansi, karena nilai signifkansinya lebih besar dari 0,05. Hal ini mengindikasi bahwa perubahan yang terjadi pada rasio pemanfaatan teknologi informasi tidak berpengaruh secara signifikan terhadap efektivitas sistem informasi akuntansi.

Berdasarkan hipotesis yang diajukan yaitu pemanfaatan teknologi informasi berpengaruh positif dan signifikan terhadap efektivitas sistem informasi akuntansi tidak dapat diterima atau ditolak. Hasil penelitian ini tidak sesuai dengan hasil penelitian dari Alaryan et al. (2014) di mana terdapat pengaruh positif dan signifikan antara teknologi informasi terhadap efektivitas sistem informasi akuntansi.

Berdasarkan hasil statistik dan pengujian hipotesis pertama menunjukkan bahwa hubungan variabel pemanfaatan teknologi informasi terhadap efektivitas sistem informasi akuntansi berpengaruh positif dan tidak signifikan dimana t hitung 1,782 lebih besar dari t tabel 1,681 dan nilai signifikan 0,082 lebih besar daripada 0,05. Berdasarkan hasil regresi tersebut dapat dinyatakan bahwa $\mathrm{H} 1$ dalam penelitian ini ditolak. 
“Jurnal Akun Nabelo" Volume 2/Nomor 1/Juli 2019 (Hal. 181 - 196)

Berdasarkan hasil analisis data, hipotesis penelitian ini tidak dapat diterima karena tidak terdapat pengaruh yang signifikan antara pemanfaatan teknologi informasi terhadap efektivitas sistem informasi akuntansi. Teori kontijensi yang dikemukakan oleh Nicolau (2000), menyatakan bahwa efektivitas sistem informasi akuntansi terjadi atas efek teknologi. Efek teknologi berkaitan dengan teknologi yang digunakan dan hal-hal yang berkaitan dengan teknologi informasi akan meningkatkan efektivitas sistem informasi akuntansi.

Alasan yang mendasari hasil penelitian ini adalah penggunaan teknologi informasi dalam hal ini adalah penggunaan komputer dan didukung oleh jaringan internet akan lebih memudahkan dalam pengolahan data-data yang dibutuhkan dalam kegiatan operasinal perusahaan. Temuan ini tidak menguatkan bahwa efektivitas sistem informasi akuntansi dipengaruhi oleh pemanfaatan teknologi informasi, khususnya pada PT X Makassar, para pegawai yang memanfaatkan komputer dan jaringan internet tidak sedikit yang mengaku mendapatkan kesulitan dalam memproses data dan transaksi operasional.

Penggunaan sarana teknologi informasi yang kurang baik seringkali dapat memicu terjadinya kesalahan-kesalahan dalam pengolahan data secara manual, sehingga hal ini tentunya akan mengurangi tingkat keefektivitasan sistem informasi akuntansi.

D.4.2. Pengaruh Kompetensi Sumber Daya Manusia terhadap Efektivitas Sistem Informasi Akuntansi

Hasil uji statistik (Tabel 2) menunjukkan bahwa secara parsial diperoleh nilai t hitung sebesar 2,903 dengan signifikansi 0,006. Rasio kompetensi sumber daya manusia berpengaruh secara parsial terhadap efektivitas sistem informasi akuntansi, karena nilai signifikansi lebih kecil daripada 0,05 . Hal ini mengindikasikan bahwa perubahan yang terjadi pada rasio kompetensi sumber daya manusia akan berpengaruh signifikan terhadap efektivitas sistem informasi akuntansi. Selain itu, koefisien transformasi regresi yang positif juga menunjukkan bahwa rasio kompetensi sumber daya manusia memiliki pengaruh positif terhadap efektivitas sistem informasi akuntansi.

Pengaruh positif yang ditunjukkan oleh kompetensi sumber daya manusia mengindikasikan bahwa apabila kompetensi sumber daya manusia mengalami kenaikan maka angka efektivitas sistem informasi akuntansi akan mengalami kenaikan pula, begitupun sebaliknya. Berdasarkan hipotesis yang diajukan yaitu kompetensi sumber daya manusia berpengaruh positif dan signifikan terhadap efektivitas sistem informasi akuntansi dapat diterima. Hasil penelitian ini sesuai dengan hasil penelitian dari Alaryan et al. (2014) yang menjelaskan bahwa semakin bagus dan maksimal kinerja sumber daya manusia maka sistem informasi akuntansi akan semakin efektif.

Berdasarkan hasil statistik dan pengujian hipotesis pertama menunjukkan bahwa hubungan variabel kompetensi sumber daya manusia terhadap efektivitas sistem informasi akuntansi berpengaruh positif dan signifikan dengan $t$ hitung 2,903 lebih besar dari t tabel 1,782 dan nilai signifikansi 0,006 lebih kecil dari 0,05. Berdasarkan hasil regresi tersebut dapat dinyatakan bahwa $\mathrm{H} 2$ dalam penelitian ini diterima. Hasil 
penelitian ini sama dengan hasil penelitian yang dilakukan oleh Alaryan et al. (2014).

Berdasarkan hasil uji data, dengan diterimanya hipotesis ini menjelaskan bahwa terdapat pengaruh yang signifikan antara kompetensi sumber daya manusia terhadap efektivitas sistem informasi akuntansi. Semakin baik kompetensi sumber daya manusia yang dimiliki perusahaan maka semakin efektif pula sistem informasi akuntansinya. Teori kontijensi yang dikemukakan oleh Nicolau (2000) menyatakan bahwa efektivitas sistem informasi akuntansi terjadi atas efek lingkungan.

Efek lingkungan berkaitan dengan lingkungan internal dan eksternal perusahaan. Pada penelitian ini, lingkungan internal yaitu sumber daya manusia. Kompetensi sumber daya manusia yang baik akan menggunakan fasilitas yang tersedia untuk mengolah data secara maksimal dan tentunya meningkatkan efektivitas sistem informasi akuntansi. Kompetensi sumber daya manusia dijelaskan juga sebagai kemampuan sumber daya manusia dalam hal ini pegawai yang bekerja dan menggunakan teknologi informasi demi menunjang kegiatan operasional perusahaan.

Temuan ini semakin menguatkan bahwa efektivitas sistem informasi akuntansi dipengaruhi oleh kompetensi sumber daya manusia, khususnya pada PT X di Makassar. Adanya berbagai fasilitas teknologi informasi yang memadai tidak akan bermanfaat apabila tidak ditunjang dengan kemampuan penggunanya. Sumber daya manusia yang terampil dalam menggunakan komputer dan perangkat teknologi lainnya akan lebih mudah dan cepat dalam mengolah data yang dibutuhkan. Hal ini tentunya akan meningkatkan efektivitas sistem informasi akuntansi.

D.4.2. Pemanfaatan Teknologi Informasi Dan Kompetensi Sumber Daya Manusia Berpengaruh Simultan Terhadap Efektivitas Sistem Informasi Akuntansi

Hasil uji statistik SPSS menunjukkan F tabel 4,07 lebih kecil dibandingkan $\mathrm{F}$ hitung 12,912 dengan nilai signifikan sebesar 0,000 lebih kesil dari tingkat signifikan 0,05 sehingga pemanfaatan teknologi informasi dan kompetensi sumber daya manusia berpengaruh positif dan signifikan terhadap efektivitas sistem informasi akuntansi. Hal ini menunjukkan bahwa seorang pegawai harus memiliki kompetensi yang baik dalam pemanfaatan teknologi informasi untuk meningkatkan efektivitas sistem informasi akuntansi pada PT X di Makassar. Hasil ini mendukung teori kontijensi.

\section{E. PENUTUP}

\section{E.1. Kesimpulan}

Penelitian ini dilakukan untuk mengetahui efektivitas sistem informasi akuntansi pada PT. X di Makassar. Variabel-variabel dalam penelitian ini adalah pemanfaatan teknologi informasi, kompetensi sumber daya manusia, dan efektivitas sistem informasi akuntansi. Berdasarkan hasil analisis dan pembahasan yang telah dilakukan mengenai pengaruh pemanfaatan teknologi informasi dan kompetensi sumber daya manusia terhadap efektivitas sistem informasi akuntansi, maka dapat diberikan kesimpulan sebagai berikut. 
“Jurnal Akun Nabelo" Volume 2/Nomor 1/Juli 2019 (Hal. 181 - 196)

1. Pemanfaatan teknologi informasi berpengaruh positif dan tidak signifikan terhadap efektivitas sistem informasi akuntansi. Pengaruh positif yang ditunjukkan oleh pemanfaatan teknologi informasi mengindikasikan bahwa semakin tingginya penggunaan atau pemanfaatan teknologi informasi akan semakin tinggi pula efektivitas sistem informasi akuntansi, begitupun sebaliknya.

2. Kompetensi sumber daya manusia berpengaruh positif dan signifikan terhadap efektivitas sistem informasi akuntansi. Pengaruh positif yang ditunjukkan oleh kompetensi sumber daya manusia mengindikasikan bahwa semakin tinggi kompetensi sumber daya manusia maka semakin meningkat pula efektivitas sistem informasi akuntansi, begitupun sebaliknya. Hasil temuan ini sama dengan hasil temuan yang dilakukan oleh Alaryan et al. (2014). Penelitian ini juga didukung oleh teori kontijensi yang dikemukakan oleh Nicolau (2000) di mana efektivitas sistem informasi akuntansi dipengaruhi oleh efek lingkungan internal, termasuk kompetensi sumber daya manusia.

3. Pemanfaatan teknologi informasi dan kompetensi sumber daya manusia berpengaruh simultan terhadap efektivitas sistem informasi akuntansi.

Penelitian ini hanya dilakukan pada PT X di Makassar sehingga hasil penelitian ini seharusnya diinterpretasikan dengan hati-hati. Peneliti menyarankan kepada peneliti selanjutnya untuk memperluas subjek penelitian sehingga diperoleh hasil penelitian yang lebih komprehensif. Selain itu, penelitian selanjutnya dapat menambah variabel lain yang belum diteliti yang diduga berpengaruh terhadap efektivitas sistem informasi akuntansi.

\section{DAFTAR PUSTAKA}

Alaryan, L.A.,Haija, Ayman A.A., and Taber, Thaer A.A. 2014. The Effectiveness of Accounting Infomation Systems in Jordanian Private Higher Education Institutions. International Journal of Accounting and Financial Reporting, (Online), Vol 4, No.1, (http://search.proquest.com)

Antasari, Kadek Chendi \& Yaniartha, Pt D'yan. 2015. Pengaruh Efektivitas Sistem Informasi Akuntansi dan Penggunaan Teknologi Informasi pada Kinerja Individual dengan Kepuasan Kerja sebagai Variabel Pemoderasi. EJurnal Akuntansi Universitas Udayana, (Online), (http://ojs.unud.ac.id).

Damayanthi, IGA Eka \& Sierrawati, Ni Luh Made. 2013. Pengaruh Efektivitas Sistem Informasi Akuntansi dan Penggunaan Teknologi Informasi terhadap Kinerja Individual. Skripsi: Denpasar, Bali.

Grande, Elena Urquia. 2011. The impact of Accounting Information Systems (AIS on Performance measures: Empirical evidence in Spanish SMEs1. The International Journal of Digital Accounting Research (Online), 11 (2), pp: 2543, (http://search.proquest.com). .

Hall, James A. 2011. Principles of Accounting Information Systems. Singapore: Cengage Learning. 
Pengaruh Pemanfaatan Teknologi Informasi dan ... Paranoan, Tandirerung, \& Paranoan

Ismanto, Agus. 2010. Pemanfaatan Teknologi Informasi Berpengaruh Terhadap Kinerja Individu Mahasiswa Jurusan Akuntansi Perbanas Surabaya. EJurnal Akuntansi Universitas Udayana 10.2(2015):354-369

Islam J. dan Hui Hu. 2012. A review of literature on contingency theory in managerial accounting. African Journal of Busines Management, (Online), Vol. 6(15), pp. 5159-5164.

Karmita, Fitriah. 2015. Pengaruh Pemanfaatan Teknologi Informasi dan Kompetensi Sumber Daya Manusia Terhadap Efektivitas Sistem Informasi Akuntansi Pada BLKI Makassar.

Nicolaou, Andreas I. 2000. A Contingency Model of Perceived Effectiveness in Accounting Information Systems: Organizational Coordination and Control Effects.international Journal of Accounting Information Systems,(Online), 1(2000):91-105, (http://search.proquest.com).

Nurillah. 2014. Pengaruh Kompetensi Sumber Daya Manusia, Penerapan Sistem Akuntansi Keuangan Daerah, Pemanfaatan Teknologi Informasi, dan Sistem Pengendalian Intern terhadap Kualitas Laporan Keuangan Daerah. Skripsi. Semarang: Fakultas Ekonomi dan Bisnis Universitas Diponegoro.

Prasojo, Lantip Diat \& Riyanto. 2011. Teknologi Informasi Pendidikan. Yogyakarta: Gava Media.

Sajady, H., Dastgir, M., Hashemnejad. 2008. Evaluation of the effectiveness of accounting information systems. International Journal of Information Science and Technology, (Online), 6(2), (http://ijism.ricest.ac.ir).

Sari, Maria, M. Ratna. 2009. Pengaruh Efektivitas Penggunaan dan Kepercayaan terhadap Teknologi Sistem Informasi Akuntansi terhadap Kinerja Individual pada Pasar Swalayan di Kota Denpasar. Jurnal Ilmiah Akuntansi dan Bisnis. Denpasar, Bali: Fakultas Ekonomi Universitas Udayana.

Sufren dan Yonathan, N. 2013. Mahir Menggunakan SPSS secara otodidak. Jakarta: Alex Media Komputindo.

Sunyoto, Danang. 2011. Analisis Regresi dan Uji Hipotesis. Jakarta: CAPS

Uno, Hamza B. \& Lamatenggo, Nina. 2011. Teknologi Komunikasi dan Informasi Pembelajaran. Bumi Aksara. Jakarta.

Warsita, Bambang. 2008. Teknologi Pembelajaran Landasan \& Aplikasinya. Jakarta: Rineka Cipta.

Widyaningrum C, dan Rahmawati. 2010. Pengaruh SDM, dan Pemanfaatan Teknologi Informasi terhadap Keterandalan dan Ketepatwaktuan Pelaporan Keuangan Pemerintah Daerah dengan Variabel Intervening Pengendalian 
“Jurnal Akun Nabelo” Volume 2/Nomor 1/Juli 2019 (Hal. 181 - 196)

Intetn Akuntansi, Studi Empiris di Pemda Subosukawonosraten. Simposium Nasional Akuntansi XII Purwokerto.

Yosefrinaldi. 2013. Pengaruh Kapasitas Sumber Daya Manusia dan Pemanfaatan Teknologi Informasi terhadap Kualitas Laporan Keuangan Pemerintah Daerah. Jurnal Akuntansi. Sumatera Barat: Fakultas Ekonomi Universitas Negeri Padang. 